\title{
Gıda ve Sağlık Uygulamaları İçin UV-A Işıma Altında Alternatif Bir Fotokatalizör Olarak: Doğal Melanin Nanoparçacıkları
}

\author{
Beyza Akman ${ }^{*}$, Buse İslam², Gizem Kaleli-Can ${ }^{1}$, Nermin Topaloğlu $^{2}$, Didem Şen Karaman ${ }^{2}$, Engin Baysoy ${ }^{1}$ \\ 1* İzmir Demokrasi Üniversitesi, Mühendislik Fakültesi, Biyomedikal Mühendisliği Bölümü, İzmir, Türkiye, (ORCID: 0000-0002-1630-9454), \\ byzakmn189@outlook.com \\ 1* İzmir Demokrasi Üniversitesi, Mühendislik Fakültesi, Biyomedikal Mühendisliği Bölümü, İzmir, Türkiye, (ORCID: 0000-0002-5896-3593), \\ islambuse@hotmail.com \\ 1* İzmir Demokrasi Üniversitesi, Mühendislik Fakültesi, Biyomedikal Mühendisliği Bölümü, İzmir, Türkiye, (ORCID: 0000-0002-4411-622X), \\ kaleligizem@gmail.com \\ 2 İzmir Katip Çelebi Üniversitesi, Mühendislik Fakültesi, Biyomedikal Mühendisliği Bölümü, İzmir, Türkiye, (ORCID: 0000-0001-7001-8327), \\ nermint@gmail.com \\ 2 İzmir Katip Çelebi Üniversitesi, Mühendislik Fakültesi, Biyomedikal Mühendisliği Bölümü, İzmir, Türkiye, (ORCID: 0000-0002-2368-9598), \\ didem.sen.karaman@ikc.edu.tr \\ 1'̇zmir Demokrasi Üniversitesi, Mühendislik Fakültesi, Biyomedikal Mühendisliği Bölümü, İzmir, Türkiye, (ORCID: 0000-0001-8323-597X), \\ enginbaysoy@gmail.com
}

(International Conference on Design, Research and Development (RDCONF) 2021 - 15-18 December 2021)

(DOI: 10.31590/ejosat.1040830)

ATIF/REFERENCE: Akman, B., İslam, B., Kaleli Can, G., Topaloğlu, N., Şen Karaman, D. \& Baysoy, E. (2021). Gıda ve Sağlık Uygulamaları İçin UV-A Işııma Altında Alternatif Bir Fotokatalizör Olarak: Doğal Melanin Nanoparçacıkları. Avrupa Bilim ve Teknoloji Dergisi, (32), 940-946.

$\ddot{O} z$

UV ışıması altında metalik nanoparçacıkların fotokatalitik etkisinin keşfedilmesinden bu yana, toksik olmayan nanoparçacıklara dayalı yenilikçi bir malzeme sınıfının geliştirilmesi, gıda ve sağlık uygulamalarında kullanılabilirlikleri nedeniyle büyük ilgi toplamıştır. Fotokatalizör metalik nanoparçacıklara sürdürülebilir, biyouyumlu, biyolojik olarak parçalanabilir bir alternatif olarak, bu çalışmada UV-A ışıması altında doğal melanin nanoparçacıklarının (MNP) fotokatalitik aktivitesi gram negatif bakteri suşu Escherichia coli (E. coli)'nin üzerinde gösterilmiştir. İlk olarak, nano boyutlu melanin nanoparçacıkları doğal kaynak mürekkep balığı (Sepia officinalis) mürekkebinden ekstrakte edilmiş ve UV-A ışıması altında singlet oksijen de dahil olmak üzere, reaktif oksijen türleri üretme inaktivasyon yetenekleri 1,3-difenilizobenzofuran (DPBF) ile tespit edilmiştir. UV-A içeren ve içermeyen MNP'nin antimikrobiyal etkinlikleri araştırılmıştır. Dinamik ışık saçılımı (DLS) analizi ve taramalı elektron spektroskopisi (SEM) görüntüleri, elde edilen MNP çapının sırasıyla $214 \pm 0,5 \mathrm{~nm}$ ve $129 \pm 30 \mathrm{~nm}$ olduğunu göstermiştir. Sadece bir dakikalık ışık uygulaması sonucunda ortamdaki DPBF'nin tamamının sönümlendiği ve MNP'nin UV-A ışıması altında ortama serbest radikaller verdiği kanıtlanmıştır. Tüm konsantrasyonlardaki deney gruplarına uygulanan bir dakikalık UV-A ışıma altındaki MNP çözeltisinin varlı̆̆ı, tek başına UV-A ışıması ile kıyaslandığında belirgin seviyede hücresel inaktivasyonu arttırdı̆̆ı gözlemlenmiştir. Bir dakikalık uygulama hücresel apoptozun \%70 düzeyinde gerçekleşmesine neden olmuş ve tüm gruplar içerisinde en iyi sonucu vermiştir.

Anahtar Kelimeler: Doğal melanin nanoparçacıkları, UV-A Işıma, Dezenfeksiyon, Fotokatalizör.

\section{As an Alternative Photocatalyst Under UV-A Irradiation for Food and Health Applications: Natural Melanin Nanoparticles}

\begin{abstract}
Since finding of photocatalytic effect of metallic nanoparticles under UV irradiation, an innovative class of materials based on nontoxic nanoparticles have gathered enormous interest owing to their usability in food and health application. As a sustainable,
\end{abstract}

*Sorumlu Yazar: kaleligizem@gmail.com 
biocompatible, biodegradable alternative to photocatalyst metallic nanoparticle, we demonstrated the photocatalytic activity of natural melanin nanoparticles under UV-A irridation for gram-negative bacterial strain, Escherichia coli (E. coli). Initially, nanosized melanin nanoparticles were extracted from natural source, cuttlefish (Sepia officinalis) ink and their inactivation capability of generating reactive oxygen species including singlet oxygen under UV-A irradiation were detected with 1,3-diphenylisobenzofuran (DPBF). The antimicrobial efficacies of MNP with and without UV-A were investigated. Dynamic light scattering (DLS) analysis and scanning electron spectroscopy (SEM) images showed that the diameter of MNP were found $214 \pm 0.5 \mathrm{~nm}$ and $129 \pm 30 \mathrm{~nm}$, respectively. As a result of only one minute of light application, all of the DPBF in the environment was quenched, and it was proven that MNP gave free radicals to the environment under UV-A irradiation. The presence of MNP solution under 1-minute UV-A irradiation applied to the experimental groups at all concentrations significantly increased cellular inactivation compared to UV-A irradiation alone and the 200 $\mu \mathrm{g} / \mathrm{ml}$ of MNP solution exposed to UV-A irradiation for 1-minute caused the cellular apoptosis to occur at the level of $70 \%$, giving the best result in all groups.

Keywords: Natural melanin nanoparticles, UV-A irradiation, Disinfection, Photocatalyst.

\section{Giriș}

Günümüzde pandemi sürecinin açık bir şekilde ortaya koyduğu üzere yüzeylerin, havanın ya da suyun patojenlerden arındırılması insan sağlı̆̆ı açısından son derece önemlidir. İnsanların yaşam alanlarında etkileşimde olduğu cisimlerin yüzeylerinde veya içerisinde bulunan bakterilerin, virüslerin, mantarların, vb. gibi mikroorganizmaların çoğalmasına ve yaşamasına engel olmak amacıyla ultraviyole (UV) 1 şık kaynağına sıklıkla başvurulmaktadır [1]. Dezenfeksiyon amacıyla kullanılan geleneksel ultraviyole lambalar, insan sağlığına zararlı civa içermesi, yüksek enerji tüketimine sahip olması ve nispeten kısa kullanım ömrüne sahip olması sebebiyle yerini cıva içermeyen, düşük maliyetli, küçük boyutlu ve daha uzun süreli 1şık yayan diyot 1şık kaynaklarına (UV LED) bırakmaya başlamıştır [2]. Ancak LED tabanlı da olsa UV 1şıma insan bağışıklık sistemini baskılayabilmekte, fotoyaşlanmaya ve mutasyona sebebiyet verebilmekte ve ayrıca karsinojenik etkileri nedeniyle insan vücudunda akut ve kronik birçok olumsuz sonuç doğurabilmektedir [3-9]. UV tabanlı dezenfeksiyon işlemlerinde etkinliği arttırmak ve uygulama süresini kısaltmak amacıyla titanyum oksit $\left(\mathrm{TiO}_{2}\right)$, çinkooksit $(\mathrm{ZnO})$ vb. gibi metal temelli nanoparçacıklardan sıklıkla yararalanılmaktadır. Fotokatalizör etkiye sahip bu nanoparçacıklar, UV 1şı̆ğ emerek, yüksek kimyasal reaktif davranış gösterirler ve kirli yer altı sularını temizlemeden, havadaki kokuyu gidermeye veya çeşitli yüzeylerin dezenfekte edilmesine kadar birçok uygulamada kullanılmaktadırlar [10-13]. UV 1şı̆̆a maruz kalan nanoparçacıkların uygulandıkları ortamda yüksek miktarda reaktif oksijen türleri oluşturması, bu yöntemi patojenlerin inaktive edilmesi için etkin kılmakla birlikte, metal temelli nanoparçacıkların uzun süreli teması, yutulması veya solunması durumunda insan sağlığına zararlı birçok yan etkinin ortaya çıktığı belirlenmiştir [13-15].

Melonazomlarda bulunan ve melanositler tarafindan üretilen melanin, doğada ömelanin (koyu kahve veya siyah renk) ve feomelanin (sarı veya kırmızı renk) olmak üzere iki farklı yapıda bulunmaktadır. [9, 16-18]. Doğal bir polimer olan melanin, memeli hayvanların gözünde, derisinde, saçında, melanomada, bunun yanı sıra mürekkep balığı (sepia officinalis), ahtapot, kalamar gibi deniz canlılarında ve ayrıca bakterilerde yoğun olarak bulunmaktadır [9, 16, 19]. Bununla birlikte biyosentetik yollarla da elde edilebilen melanin, bu şekilde üretildiğinde DOPA-melanin, dopamin melanin, 5,6-dihidroksindol melanin, sistein DOPA vb. gibi adları almaktadır [16].

Melaninin biyolojik olarak kolay parçalanabilir, biyouyumlu ve antioksidan olması gibi özellikleri ile insan sağlığına herhangi bir yan etkisi olmayan bir biyomalzemedir [9, 19, 20]. UV ışığın zararlı etkilerine karşı dokuları koruyucu özelliği ile bilinen melaninin yapısında, belirli dalga boyları ve doz miktarlarında UV 1şımaya maruz kaldığında çeşitli değişimler meydana gelebilmektedir [9, 21]. Özellikle görünür 1şığın altındaki dalga boylarında daha çok görülen bu durum, melaninin ortamdaki oksijeni tüketerek çevreye süperoksit, hidrojen peroksit, singlet oksijen gibi serbest radikaller salmasına ve canlı hücreler üzerinde DNA hasarını arttırıcı foto oksidasyon yaratmasına sebep olmaktadır [9, 17, 18, 22-24]. Yapılan çalışmalarda özellikle UV-A ve UV-B dalga boylarındaki 1şıma altında, melaninin yüksek miktarda aktif oksijen türleri oluşturduğu ve nihayetinde canlı hücreleri apoptoza uğrattığı gösterilmiştir [9, $17,18,23,25,26]$. Bu çalışma, günümüzde çeşitli dalga boylarındaki UV ışıması altında yapılan dezenfeksiyon işlemlerinde rutin olarak kullanılan, ancak insan sağlığına zararlı etkileri bilinen fotokatalizör parçacıklardan $\left(\mathrm{TiO}_{2}, \mathrm{ZnO}\right.$, vb. gibi) yararlanmak yerine, güneş 1şığında yüksek miktarda bulunan (>\%95) ve insanların bulunduğu ortamlarda kullanılabilen UV-A 1şıma altında patojenlerin etkili bir şekilde inaktive edilmesi için biyoparçalanabilir, biyouyumlu ve herhangi bir toksik etkisi olmayan melanin nanoparçacıklarının kullanılabilmesini incelemektedir.

\section{Materyal ve Metot}

\subsection{UV-A LED Işık Kaynağı Tasarımı}

Deneylerde kullanılmak üzere 395-400 nm dalga boyunda 1şıma yapabilen 9 adet SMD LED (Cree 3535) lehimlenerek, 3X3'lük matris haline getirilmiş ve tek parça bir ışık kaynağı elde edilmiştir. UV-A LED 1şık kaynağı bakteri soluüsyonlarının bulunduğu kuyucuklara yatay olarak pozisyonlandırılmış olup, kuyucuklar ile 1şık kaynağı arasındaki mesafe $1 \mathrm{~cm}$ dir. UV-A 1şık kaynağının $1 \mathrm{~cm}$ mesafeden 1şık şiddeti Optomed Ölçüm ve Kalibrasyon Laboratuvarı'nda kalibrasyonu yapılan radyometre (Deltaohm) ve LP471UVA ölçüm probu ile $3400 \mu \mathrm{W} / \mathrm{cm}^{2}$ değerinde ölçülmüştür.

\subsection{Doğal Melanin Nanoparçacık Çözeltisi Hazırlanması}

$\mathrm{Bu}$ çalışmada melanin nanoparçacıkları mürekkep balığının (Sepia officinalis) mürekkebinden elde edilmiştir. Ticari olarak Ekol Gıda Ürünlerinden satın alınan mürekkep balığının mürekkebi distile su ile sulandırılmış ve stok elde edilmiştir. Elde edilen melanin stoğu, 1:5 oranında seyreltilmiş ve 1 dakika boyunca vorteks yardımıyla karıştırılmıştır. Vorteksle karıştırılan ependorflar 20 dakika boyunca 10000 rpm'de santrifüjlenmiştir. Santrifüj işlemi sonucunda elde edilen süpernatant mikropipet yardımıyla uzaklaştırılmıştır. Pelet üzerine $1500 \mu \mathrm{l}$ saf su eklenmiş ve 1 dakika boyunca vorteks yardımı ile karıştırılmıştır. Melanin içerisinde bulunan tuz ve kirlilikleri uzaklaştırmak için yapılan bu ekstraksiyon işlemi 4 defa daha gerçekleştirilmiştir. 
Toplamda 5 döngüde gerçekleştirilen bu ekstraksiyon işlemi tamamlandığında melanin içerisinde bulunan tuz ve kirlilikler uzaklaştırılmıştır. Ependorf tüplerin dibinde biriken koyu renkli pelet mikropipet yarımdiyla ayrı bir beherde toplanarak $50^{\circ}$ derecede 1-2 gün boyunca kuruması için etüv cihazına bırakılmıştır.

Stok melanin nanoparçacık çözeltisi, her deneyden önce distile su kullanılıp seyreltilerek farklı konsantrasyonlarda hazırlanmıştır. Stok solüsyon kullanılarak farklı deney gruplarına göre çeşitli konsantrasyonlar hazırlanmış ve hazırlanan melanin çözeltisi deneyden önce 12 saat boyunca sonikatörde tutulmuştur. Çeşitli deneyler için 100, 200 ve $400 \mu \mathrm{g} / \mathrm{ml}$ MNP konsantrasyonları kullanılmıştır.

\subsection{Doğal Melanin Nanoparçacıklarının Karakterizasyonu}

Nanoparçacık büyüklüğü SEM ve Zeta-size teknikleriyle analiz edilmiştir. İki teknik, sırasıyla mutlak boyut ve hidrodinamik çap olmak üzere iki farklı parçacık çapını elde etmemizi sağlamıştır. Sadece Zeta-size tekniğinin kullanımı, melanin gibi agglomere olmaya eğilimli olan parçacıklarda yeterli değildir [27]. Bu sebeple, melanin nanoparçacıklarının analizinde sonuçların birbirini desteklemesi için her iki teknik birlikte kullanılmıştır. Doğal melanin nanoparçacıklarının (MNP) mutlak boyutunu belirlemek için SEM (FEI-Quanta 400F, ABD) kullanılmıştır. Elde edilen doğal nanoparçacıklar, son konsantrasyonu $0,025 \mathrm{mg}$ / mL olacak şekilde saf suda ayrı ayrı süspanse edilmiş ve 1 saat boyunca sonike edilmiştir. Sonikasyon sonrasında, örnekler oda sıcaklığında ve karbon yüzeyler üzerinde kurutulmuştur. Örnekler inceleme öncesinde elektrik iletkenliğini artırmak için altınpaladyum (Au-Pd) karışımı ile kaplanmıştır. Diğer analiz tekniği olan dinamik ışı saçılımı tekniği, partikül büyüklüğünü ve çoklu dağılma indeksini (PDI) analiz etmek için kullanılmıştır. Elde edilen örnekler, son konsantrasyonu $0,025 \mathrm{mg} / \mathrm{mL}$ olacak şekilde saf suda ayrı ayrı süspanse edilmiş ve 1 saat boyunca sonike edilmiştir. Sonikasyon sonrasında, süspansiyonlar Malvern kuvars küvetine aktarılıp analiz edilmiştir. Tüm deneyler $25^{\circ} \mathrm{C}$ 'de gerçekleştirilmiştir.

Doğal melanin nanoparçacıklarının morfolojik yapısının yanısıra nanoparçacıkların kimyasal yapısı, ATR (Attenuated Total Reflectance) tekniği kullanarak Fourier Transform Infrared (FTIR) spektroskopi (Perkin Elmer Spectrum Two, Waltham, MH, USA) ile analiz edilmiştir. ATR-FTIR spektrumları 4000$1000 \mathrm{~cm}^{-1}$ arasında kaydedilmişstir.

Son olarak, doğal melanin nanoparçacıklarının termal özellikleri nitrojen altında $10{ }^{\circ} \mathrm{C} / \mathrm{dk}^{\prime}$ lık bir 1sıtma hızında termal gravimetrik analiz (TGA, TA Instruments Co., DE, ABD) kullanılarak analiz edilmiştir. Termal stabilite çalışması için yaklaşık $4 \mathrm{mg}$ nanoparçacık kullanılmış ve bunların bozunma sıcaklıkları değerlendirilmiştir. Argon (40 mL/dak) analiz sırasında püskürtme gazı olarak kullanılmıştır. Numuneler alüminyum kaplara yerleştirilip ve $10^{\circ} \mathrm{C} /$ dakikalık bir 1 sıtma hızında $20^{\prime}$ den $600^{\circ} \mathrm{C}^{\prime}$ ye kadar isitılmıştır.

\subsection{Bakteri Çözeltisi Hazırlanması}

Bu çalışmada Escherichia coli (E. coli) ATCC 25922 suşu kullanılmış olup, bakteriler $-80^{\circ} \mathrm{C}$ 'de saklanan donmuş stoklardan açılarak besi yerine ekilmiştir. Bakteri suşu örneği, çizme plak (streaking) yöntemi ile tyriptik soy agar (TSA) üzerine aktarılmış ve gece boyunca $37^{\circ} \mathrm{C}^{\prime} \mathrm{de}$ inkübe edilmiştir. Bir gecelik inkübasyon periyodundan sonra, agar üzerinden tek bir koloni seçilmiş ve $5 \mathrm{ml}$ tyriptik soy sıvı besi yeri (TSB) içinde inoküle etmek için bir orbital çalkalayıcı (180 rpm) içinde $37^{\circ} \mathrm{C}^{\prime} \mathrm{de}$ gece boyunca kültürlenmiştir. Orbital çalkalayıcıdan alınan bakteri süspansiyonu santrifüjlenmiş ve dikkatli bir şekilde süpernatant TSB çıkarılmıştır. Pelet (bakteri) $1 \mathrm{ml}$ PBS içinde çözülerek yaklaşık 1x108 CFU/ml konsantrasyonunda bakteri süspansiyonu elde edilmiştir.

\subsection{Deneysel Tasarım}

UV-A 1şıma altında fotokatalizör olarak kullanılan MNP bakteriyel inaktivasyonu performansını ölçmek için, her bir deneyde $250 \mu$ l bakteri çözeltisi ile çeşitli konsantrasyonlarda 250 $\mu 1 \mathrm{MNP}$ çözeltisi 24 oyuklu bir plaka içinde bir araya getirilmiştir ve toplam 4 saat inkübe edilmiştir. Deneylerde ayrı ayrı 100, 200 ve $400 \mu \mathrm{g} / \mathrm{ml} \mathrm{MNP}$ içeren çözeltiler kullanılmıştır. Her grup için, 24 oyuklu plakalar üzerinde 3 farklı numune tekrarlanmıştır. 4 saatlik inkübasyon periyodundan sonra PBS yardımıyla 1/10 oranında seri seyreltme yöntemi uygulanmıştır. Sonrasında seyreltilen süspansiyonlardan alınan $100 \mu$ l'lik örnekler agar üzerinde yayılarak 24 saat inkübasyona bırakılmıştır. 24 saat sonunda ise bakteri sayımı yapılmıştır. Araştırılan gruplar aşağıdaki gibidir:

- Kontrol Grubu: Nanoparçacık ve ultraviyole uygulanmayan grup.

- Melanin Grubu: Yalnızca MNP bulunan grup.

- UV Grubu: Sadece UV uygulanan grup.

- UV+Melanin Grubu: MNP ve UV kombinasyonunun uygulandığ grup.

Melanin grupları için, 0,04 gram MNP ve $1 \mathrm{ml}$ saf su içerisinde çözülerek stok solüsyonu hazırlanmıştır. $100 \mu \mathrm{g} / \mathrm{ml}$ konsantrasyonda $1 \mathrm{ml}$ çözelti hazırlamak için hazırlanan stoktan $50 \mu \mathrm{l}$ melanin stok solüsyonu ve $950 \mu \mathrm{l}$ saf su alınarak test tüpüne konulmuştur. $200 \mu \mathrm{g} / \mathrm{ml}$ konsantrasyonda $1 \mathrm{ml}$ çözelti hazırlamak için hazırlanan stoktan $100 \mu \mathrm{l}$ melanin stok solüsyonu alınıp, 900 $\mu \mathrm{l}$ saf ilave edilerek test tüpüne konulmuştur. $400 \mu \mathrm{g} / \mathrm{ml}$ konsantrasyonda $1 \mathrm{ml}$ çözelti hazırlamak için hazırlanan stoktan $200 \mu \mathrm{l}$ melanin stok alınarak, üzerine $800 \mu \mathrm{l}$ saf su eklenerek test tüpüne konulmuştur. Tüm test tüpleri bir sonikatör yardımıyla 24 saat boyunca homojen bir şekilde karıştırılmıştır. Melanin konsantrasyonlarının her birinin $250 \mu$ l'si alınarak, 24 oyuklu plakanın farklı oyuklarında $250 \mu \mathrm{l}$ bakteri ile birleştirilmiş ve 4 saat boyunca inkübasyona tabi tutulmuştur.

$\mathrm{UV}+$ Melanin grubu uygulamaları için yukarıdaki konsantrasyonlarda hazırlanan melanin çözeltisi ve bakteri karışımı solüsyonları hazırlanarak, 4 saat inkübe edildikten sonra 30 saniye, 1 dakika, 5 dakika, 10 dakika ve 30 dakika UV-A 1şıması uygulanmıştır. UV grubunda ise, hücreler nanoparçacık ile inkübe edilmeden belirtilen sürelerde sadece UV-A 1şımasına maruz bırakılmışlardır. Kontrol grubuna herhangi bir uygulama yapılmamış olup, bu gruptan elde edilen veriler diğer grupların sonuçları ile karşılaştırmak için kullanılmışladır. Her parametre değişikliği için farklı deney seti hazırlanmıştır.

\subsection{Seri Seyreltme Yöntemi ile Bakteriyel Hücre Canlılığı Analizi}

Deneylerde uygulamalar sonrasında canlı kalan bakteri sayısını tespit etmek için seri seyreltme yönteminden yararlanılmıştır. Orijinal numunede sayılamayacak kadar çok bakteri bulunduğundan seyreltme işlemi kademeli olarak gerçekleştirilir. 
Kuyulardaki bakteri sayısını hesaplamak için bu solüsyonun seyreltme faktörü $1 / 10$ 'dur. Bütün deney gruplarında uygulama sonrasında elde edilen numunenin $20 \mu$ l'si alınmış ve bir oyukta $180 \mu \mathrm{l}$ PBS ile birleştirilmiştir. Daha sonra bu kuyudan $20 \mu \mathrm{l}$ alınıp, diğer kuyuda bulunan $180 \mu$ PBS ile birleştirilmiştir. Bu işlem, istenen seyreltme elde edilene kadar kademeli olarak tekrarlanmıştır. TSA kaplı plakalara $100 \mu \mathrm{l}$ seyreltilmiş solüsyon ilave edilmiş ve gece boyunca $37^{\circ} \mathrm{C}^{\prime} \mathrm{de}$ inkübe edilmiştir. $\mathrm{Bu}$ sürecin sonunda bakteriler görünür hale gelmiştir. Agar üzerindeki bakteri koloni sayısı sayıldıktan sonra seyreltme faktörü ile çarpılarak uygulamalar sonunda elde edilen canlı bakteri sayısı tespit edilmiştir.

\subsection{Reaktif Oksijen Türlerinin DPBF ile Analizi}

1,3-Difenilisobenzofuran (DPBF) çözeltisi, UV 1şıması altında MNP'lerinin uygulanılan ışınlama sürelerinde ortama saldığı radikal grup miktarlarının analizi için kullanılmıştır. DPBF çözeltisi hazırlamak için $0,4 \mathrm{mg}$ DPBF ve $200 \mu \mathrm{l}$ DMSO test tüpünde bir araya getirildikten sonra 5 dakika süreyle ultrasonik homojenizatörde bekletilmiştir. Elde edilen DPBF çözeltisinden 4 $\mu \mathrm{l}, 100 \mu \mathrm{g} / \mathrm{ml}$ konsantrasyondaki melanin çözeltisinden ise $200 \mu \mathrm{l}$ alınarak 96 oyuklu bir plakada 2 numune olacak şekilde bir araya getirilmiştir. Belirli bir süre bu karışımı inkübe ettikten sonra, bu karşımın 300-600 nm aralığında absorbans spektum analizi mikroplaka okuyucu yardımıyla gerçekleştirilmiştir.

\subsection{Veri ve İstatistik Analizi}

Bakteri koloni sayıları çıplak gözle sayılarak kontrol grubu ile karşılaştırılmıştır. Kontrol grubu ile deney grupları arasında istatiksel düzeyde anlamlı bir değişim olup olmadığı Student ttesti kullanılarak karşılaştırılmıştır. İstatistiksel analiz sonucunda 0,05 'ten küçük elde edilen değerler anlamlı kabul edilmiştir.

\section{Araştırma Sonuçları ve Tartışma}

\subsection{Doğal Melanin Nanoparçacıklarının Karakterizasyonu}

Zetasizer analizi ile hidrodinamik çap analizi sonucunda melanin nanoparçacığının boyutu $214 \pm 0,5 \mathrm{~nm}$ ve çoklu dağılma indeksi (PDI) 0,132 \pm 0.005 olarak bulunmuştur. Şekil 1.'de gösterilmiş olan taramalı elektron mikroskop analizi sonucunda ise melanin nanoparçacıklarının mutlak boyutu $129 \pm 30 \mathrm{~nm}$ olarak gözlemlenmiştir. Mutlak boyut ve hidrodinamik çap arasındaki fark melanin nanoparçacıklarının su ortamında agglomere olduğuna işaret etmektedir.

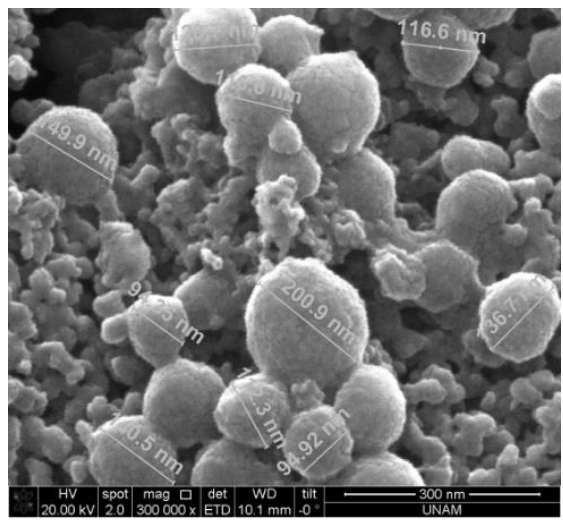

Şekil 1. Doğal melanin nanoparçacıklarının taramalı elektron mikroskop görüntüsü
Melanin nanoparçacıklarının kimyasal yapısı ATR-FTIR analizi ile incelenmiş ve Grafik 1'de gösterilmiştir. Spektrumda karboksilik asit ve fenolik yapı kaynaklı $\mathrm{OH}$ ve $\mathrm{NH}_{2}$ titreşimleri 3620 ila $2660 \mathrm{~cm}^{-1}$ arasında geniş bir tepe olarak gözlemlenmiştir. $\mathrm{Bu}$ yapılar aromatik amino foksiyonel gruplara sahip indolik ve pirolik yapılarda da görülmektedir. Ayrıca $\mathrm{CH}$ band gerilmesi (2920 $\left.\mathrm{cm}^{-1}\right)$, kinon veya ketonda COO- yapısındaki $\mathrm{C}=\mathrm{O}$ 'nun gerilmesi $\left(1630 \mathrm{~cm}^{-1}\right), \mathrm{C}=\mathrm{C}$ aromatik halkanın titreşimi/ COO'nin simetrik gerilmesi $\left(1453 \mathrm{~cm}^{-1}\right)$, pirol halkasının gerilmesi (1388 $\left.\mathrm{cm}^{-1}\right)$, CH düzlem içi deformasyonu $\left(1248 \mathrm{~cm}^{-1}\right)$ ve pirol $\mathrm{NH}$ düzlem içi deformasyonu $\left(1164 \mathrm{~cm}^{-1}\right)$ kaynaklı bantlar gözlemlenmiştir.

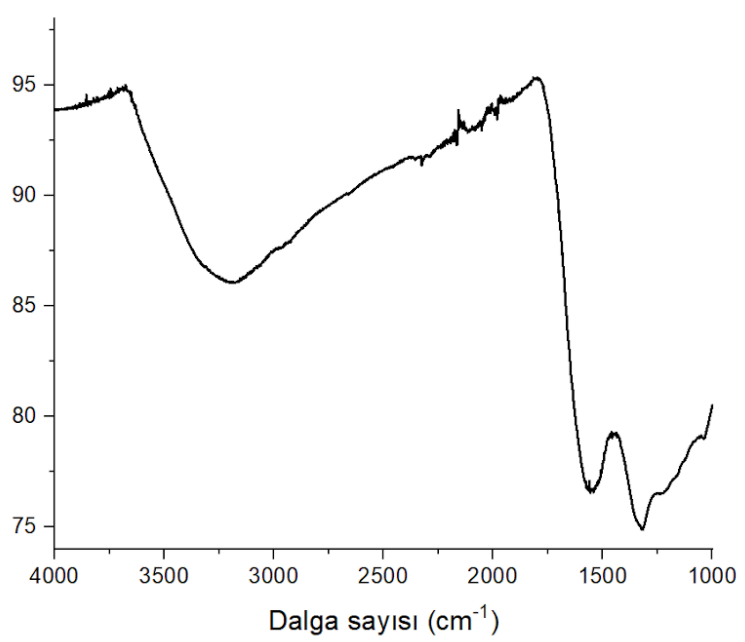

Grafik 1. Melanin nanoparçacıklarının ATR-FTIR spektrumu

Melanin nanoparçacıklarının termal darvranışı için termogravimetrik analizi gerçekleştirilmiş ve Grafik 2'de verilmiştir. Grafikteki eğride görüldüğü gibi melanin iki basamaklı bir bozunma gerçekleştirmiştir. Melaninde serbest su ve/veya bağlı su kaybına karşılık gelen $34^{\circ} \mathrm{C}$ ve $224^{\circ} \mathrm{C}$ arasında gözlemlenmiştir. Termal bozunmanın ikinci aşaması $224^{\circ} \mathrm{C}$ 'de başlamış ve bu aşamada melanin yapısında bulunan kovalent olmayan bağların bir kısmı kırılmıştır. Kütle kaybı profilini anlamak için $600^{\circ} \mathrm{C}^{\prime}$ ye kadar termogravimetrik analiz sürdülmüştür, ancak bu süre içinde baştaki melanin kütlesinin sadece yaklaşık \%64'ünün kaybolduğu gözlemlenmiştir. Melaninin termal kararlılığı, grafit benzeri yapısından kaynaklanmaktadır [28].

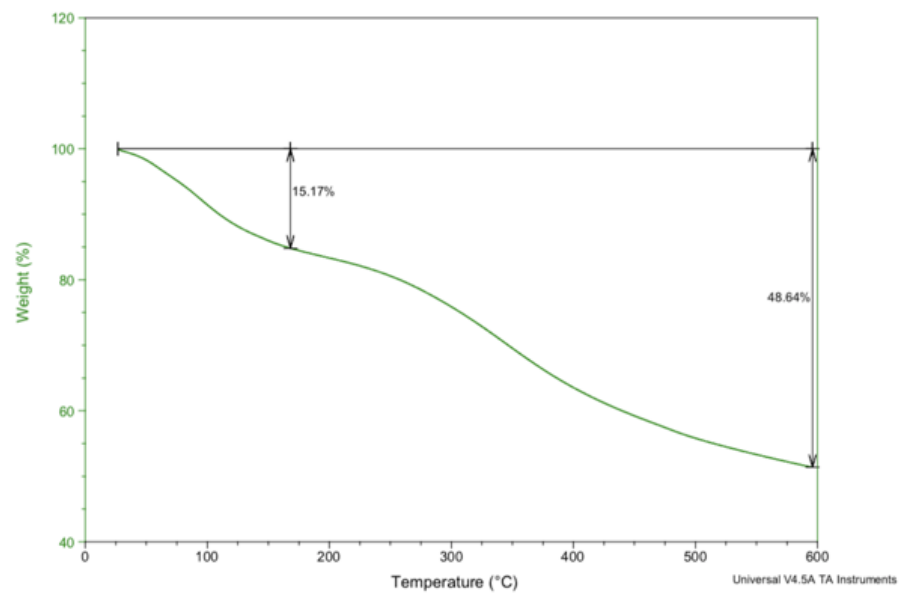

Grafik 2. Doğal melanin nanoparçacıklarının termal bozunma eğrisi 


\subsection{UV-A Işıma Altında DPBF-Melanin Testi}

DPBF ve MNP'nın bir araya getirilmesi ile elde edilen çözelti, 30 saniye süreyle UV-A ışımaya maruz bırakılmıştır. Öncelikle $100 \mu \mathrm{g} / \mathrm{ml}$ konsantrasyonda olan MNP çözeltisi, 1 dakika boyunca UV-A ışımasına maruz birakıldıktan sonra ortamda radikal grup salınıp, salınmadığı incelenmiştir. Ortamda oluşan singlet oksijen molekülleri DPBF maddesine bağlanarak etkinliğini yitirmesine ve 415-nm'de bir absorbans değeri vermemesine sebep olmaktadır. Grafik 3'te gösterilen değerler 1şığında, 1 dakikalık ışık uygulaması sonucunda ortamda var olan DPBF kimyasalının tamamı sönümlenmiş olup MNP'nın UV-A ışıma altında serbest radikalleri ortama verdiği kanıtlanmıştır.

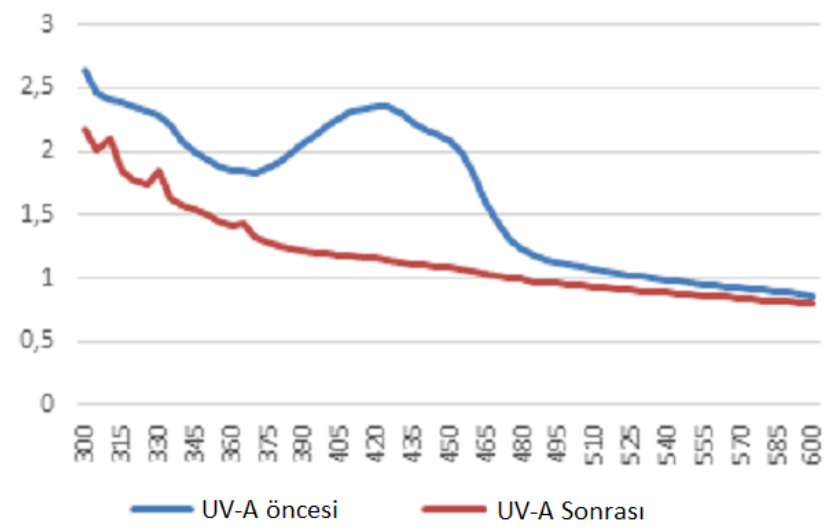

Grafik 3. UV-A ışıma altında MNP'nin ortama verdiği radikal gruplarının DPBF çözeltisi ile ölçülmesi

\subsection{UV-A Işıma Altında Farklı Melanin Konsantrasyonlarının $E$. coli Üzerindeki Etkileri}

$\mathrm{Bu}$ deneyde $100 \mu \mathrm{g} / \mathrm{ml}, \quad 200 \mu \mathrm{g} / \mathrm{ml}$ ve $400 \mu \mathrm{g} / \mathrm{ml}$ konsantrasyonlarındaki MNP çözeltilerinin farklı UV-A 1şıma sürelerine maruz kalmaları durumunda $E$. coli üzerindeki etkileri araştırılmış ve detayları Grafik 4'te gösterilmiştir. Farklı konsantrasyonlarda hazırlanan UV+Melanin Gruplarında 30 saniyelik UV-A ışıması altında etkin bir dezenfeksiyon sonucu gözlemlenmemiştir. Buna neden olarak 30 saniyelik UV-A ışımasının melanin nanoparçacıklarının fotokatalizör etkisini ortaya çıkarmak için yeterli dozu oluşturmadığı düşünülmektedir. Tüm konsantrasyonlardaki deney gruplarına uygulanan 1 dakikalık UV-A 1şıma altındaki MNP çözeltisinin varlığı, tek başına UV-A ışıması ile kıyaslandığında belirgin seviyede hücresel inaktivasyonu arttırmıştır. 1 dakikalık UV-A ışımasına maruz kalan $200 \mu \mathrm{g} / \mathrm{ml}$ konsantrasyon MNP çözeltisi, \%70 seviyesinde hücresel apoptoz meydana gelmesine sebep olarak, tüm gruplardaki en iyi sonucu vermiştir. MNP çözeltisi 5 dakikalık 1şıma altında da benzer şekilde tüm konsantrasyonlar için fotokatalizör etkisini belirgin şekilde göstermiştir. Deney gruplarına uygulanan 10 ve 30 dakikalık UV-A ışımasında ise MNP çözeltisi bakterilerin inaktivasyonu yerine, alışıldık UV altındaki korumacı özelliğini sergilediği gözlemlenmiştir. $\mathrm{Bu}$ durum ise MNP çözeltisinin mevcut konsantrasyon değerleri ve uzun ışıma süreleri ile orantılı olarak, ortamdaki oksijen seviyesindeki azalma sebebiyle serbest radikal salınımı davranışının kaybolduğu şeklinde yorumlanmıştır.

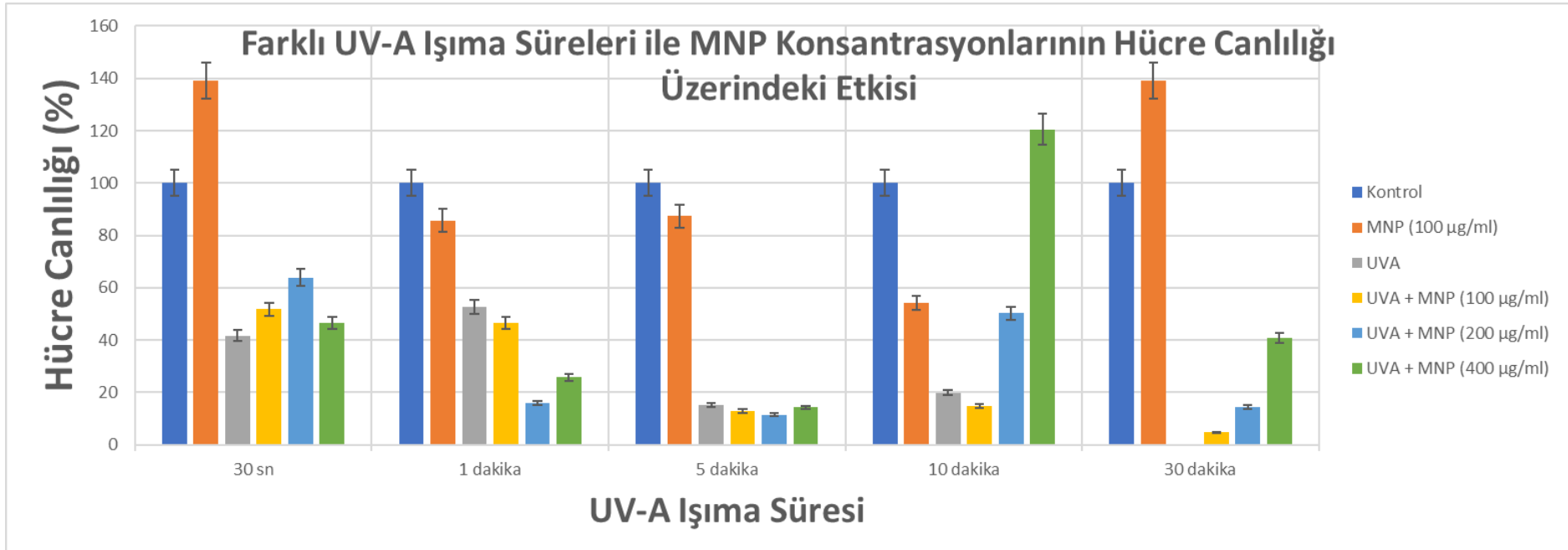

Grafik 4. Farklı UV-A ışıma sürelerine maruz kalan farklı konsantrasyonlardaki MNP çözeltilerinin E. coli canlılı̆̆ üzerindeki etkisi

\section{Sonuç}

Melanin pigmentinin yapısındaki UV ışı̆̆ı soğurucu özelliği sayesinde, canlıları güneşin zararlı ışınlarına karşı koruyucu etkisi günümüzde herkes tarafindan bilinmektedir. Ancak nanoparçacık boyutundaki melanin, belirli dozda UV ışığa maruz kalması durumunda yapısında değişim meydana gelmekte ve bir fotokatalizör davranışı sergilemektedir. Bu çalışmada günümüzde insan sağlığına zararlı etkileri bilinmesine rağmen, çok çeşitli ortamların dezenfeksiyonu için sıklıkla kullanılan metal içeren nanoparçacıkların yerine, alternatif olarak insanla ve doğa ile dost MNP'ların bir fotokatalizör olarak kullanılabileceğine dair sonuçlar ortaya konmuştur. Özellikle gıda sektöründe veya sağlık alanında metal içerikli fotokatalizörlerin oluşturduğu riskler söz konusu olduğunda, biyouyumlu ve biyoparçalanabilir MNP'ların ciddi bir seçenek oluşturduğu düşünülmektedir. Bununla birlikte UV-A 1şımaya maruz kalan MNP'ların fotokatalizör olarak verimliliği ışık doz miktarına, ışık kaynağının konumuna, 
melanin konsantrasyonuna ve çevresel koşullara bağlı olarak değişebilmektedir. Bu sebeple farklı değişkenler kullanılarak yeni deneyler yapılması ve MNP'ların fotokatalizör olarak kullanılabilecekleri optimum değerlerin tespit edilmesi gelecekte tarafımızdan hedeflenmektedir.

\section{Teşekkür}

$\mathrm{Bu}$ çalışma TUBITAK 2209-A proje desteği tarafindan fonlanmıştır. Yazarlar bu çalışmaya verdiği maddi ve manevi destek sebebiyle Sayın Mustafa Kemal Altınel'e ve EPS firmasına şükranlarını sunmaktadır. Ayrıca yazarlar, deneysel çalışmalar sırasında yardımlarından ve emeklerinden dolayı Sayın Emel Bakay'a teşekkürü borç bilirler.

\section{Kaynakça}

[1] Jo, W. K., and Tayade, R. J. (2014). New generation energyefficient light source for photocatalysis: LEDs for environmental applications. Industrial and Engineering Chemistry Research, 53(6), 2073-2084.

[2] Pal, A., Alam, S., Mittal, S., Arjaria, N., Shankar, J., and Kumar, M. et al. (2016). UVB irradiation-enhanced zinc oxide nanoparticles-induced DNA damage and cell death in mouse skin. Mutation Research/Genetic Toxicology And Environmental Mutagenesis, 807, 15-24. doi: 10.1016/j.mrgentox.2016.06.005

[3] Harsanyl, Z., Post, P., Brinkmann, J., Chedekel, M., and Deibel, R. (1980). Mutagenicity of melanin from human red hair. Experientia, 36(3), 291-292. doi: 10.1007/bf01952282

[4] Ullrich, SE. (2002). Photoimmune suppression and photocarcinogenesis. Front Biosci, 7, 684-703.

[5] Ziegler, A., Jonason, A., Leffellt, D., Simon, J., Sharma, H., \& Kimmelman, J. ... Brash, D. (1994). Sunburn and p53 in the onset of skin cancer. Nature, 372(6508), 773-776. doi: $10.1038 / 372773 \mathrm{a} 0$

[6] Nghiem, D., Kazimi, N., Clydesdale, G., Ananthaswamy, H., Kripke, M., and Ullrich, S. (2001). Ultraviolet A Radiation Suppresses an Established Immune Response: Implications for Sunscreen Design. Journal Of Investigative Dermatology, 117(5), 1193-1199. doi: 10.1046/j.0022-202x.2001.01503.x

[7] Yoshikawa, T., Rae, V., Bruins-Slot, W., van den Berg, J., Taylor, J., and Streilein, J. (1990). Susceptibility to Effects of UVB Radiation on Induction of Contact Hypersensitivity as a Risk Factor for Skin Cancer in Humans. Journal Of Investigative Dermatology, 95(5), 530-536. doi: 10.1111/1523-1747.ep12504877

[8] Elmets, C., Bergstresser, P., Tigelaar, R., Wood, P., and Streilein, J. (1983). Analysis of the mechanism of unresponsiveness produced by haptens painted on skin exposed to low dose ultraviolet radiation. Journal Of Experimental Medicine, 158(3), 781-794. doi: 10.1084/jem.158.3.781

[9] Brenner, M., and Hearing, V. (2007). The Protective Role of Melanin Against UV Damage in Human Skin $\dagger$. Photochemistry And Photobiology, 84(3), 539-549. doi: 10.1111/j.1751-1097.2007.00226.x

[10] Yang, Q., and Ma, Y. (2014) Irradiation-Enhanced Cytotoxicity of Zinc Oxide Nanoparticles. Int J Toxicol, e-ISSN: 2148-2683
33(3), 187-203. doi: 10.1177/1091581814529168. Epub 2014 Apr 3. PMID: 24700570.

[11] Google Patents. (2021). Retrieved 29 November 2021, from https://patents.google.com/patent/US6902397?oq=UVA+des enfectio

[12] Rastkari, N., Eslami, A., Nasseri, S., Piroti, E., Asadi, A. (2017). Optimizing Parameters on Nanophotocatalytic Degradation of Ibuprofen Using UVC/ZnO Processes by Response Surface Methodology. Polish Journal of Environmental Studies, 26(2), 785-794. https://doi.org/10.15244/pjoes/64931

[13] Kaplan, A., Akalın, G. Ç., Kutlu, H. M. (2017). Titanyum Dioksitin A549 Hücreleri Üzerindeki Apoptotik Etkileri. Anadolu Üniversitesi Bilim ve Teknoloji Dergisi: C-Yaşam Bilimleri ve Biyoteknoloji, 6(1), 38 - 54.

[14] Osmond, M. J., and Mccall, M. J. (2010). Zinc oxide nanoparticles in modern sunscreens: An analysis of potential exposure and hazard. Nanotoxicology, 4(1), 15-41.

[15] Geng, J., Tang, W., Wan, X., Zhou, Q., Wang, X., Shen, P. ... Lei, T. C. (2008). Photoprotection of bacterial-derived melanin against ultraviolet A-induced cell death and its potential application as an active sunscreen. Journal Of The European Academy Of Dermatology And Venereology, 22(7), 852-858. doi: 10.1111/j.1468-3083.2007.02574.x

[16] Prota, G. (1995). The chemistry of melanins and melanogenesis. Fortschritte der Chemie organischer Naturstoffe $=$ Progress in the chemistry of organic natural products. Progres dans la chimie des substances organiques naturelles, 64, 93-148. https://doi.org/10.1007/978-3-70919337-2 2.

[17] Takeuchi, S., Zhang, W., Wakamatsu, K., Ito, S., Hearing, V., Kraemer, K., \& Brash, D. (2004). Melanin acts as a potent UVB photosensitizer to cause an atypical mode of cell death in murine skin. Proceedings Of The National Academy Of Sciences, 101(42), 15076-15081. doi: 10.1073/pnas.0403994101

[18] Kalyanaraman, B., Felix, C., \& Sealy, R. (1982). Photoionization of Melanin Precursors: An Elcectron Spin Resonance İnvestigation Using the Spin Trap 5,5-Dimethyl1-Pyrroline-1-Oxide (DMPO). Photochemistry And Photobiology, 36(1), 5-12. doi: 10.1111/j.17511097.1982.tb04332.x

[19] Caldas, M., Santos, A., Veiga, F., Rebelo, R., Reis, R., \& Correlo, V. (2020). Melanin nanoparticles as a promising tool for biomedical applications - a review. Acta Biomaterialia, 105, 26-43. doi: 10.1016/j.actbio.2020.01.044

[20] Mbonyiryivuze, A., Omollo, I., Ngom, B.D., Mwakikunga, B.W., Dhlamini, S.M., Park, E., ... Maaza, M. (2015). Natural Dye Sensitizer for Grätzel Cells: Sepia Melanin. Physics and Materials Chemistry, 3(1), 1-6.

[21] Akman, B., Islam B., Kaleli-Can, G, Baysoy, E., Topaloglu N., Karaman, D.S. (2021) "The Protective Role of Natural Melanin Nanoparticles Under UVC Exposure," Medical Technologies Congress (TIPTEKNO), pp. 1-4. doi: 10.1109/TIPTEKNO53239.2021.9633009.

[22] Felix, C.C., Hyde, J.S., Sarna, T.J., and Sealy, R.C. (1978). Melanin photoreactions in aerated media: electron spin 
resonance evidence for production of superoxide and hydrogen peroxide. Biochemical and biophysical research communications, 84(2), 335-41.

[23] Kvam, E., and Tyrrell, R. (1999). The Role of Melanin in the Induction of Oxidative DNA Base Damage by Ultraviolet A Irradiation of DNA or Melanoma Cells. Journal Of Investigative Dermatology, 113(2), 209-213. doi: 10.1046/j.1523-1747.1999.00653.x

[24] Marrot, L., Belaidi, J. P., Meunier, J. R., Perez, P., \& Agapakis-Causse, C. (1999). The human melanocyte as a particular target for UVA radiation and an endpoint for photoprotection assessment. Photochemistry and photobiology, 69(6), 686-693.

[25] Kipp, C., and Young, A. R. (1999). The soluble eumelanin precursor 5,6-dihydroxyindole-2-carboxylic acid enhances oxidative damage in human keratinocyte DNA after UVA irradiation. Photochemistry and photobiology, 70(2), 191198.

[26] Kvam, E., and Dahle, J. (2004). Melanin Synthesis may Sensitize Melanocytes to Oxidative DNA Damage by Ultraviolet A Radiation and Protect Melanocytes from Direct DNA Damage by Ultraviolet B Radiation. Pigment Cell Research, 17(5), 549-550. doi: 10.1111/j.16000749.2004.00168.x

[27] De Trizio, A., Srisuk, P., Costa, R. R., Fraga, A. G., Modena, T., Genta, I., ... Reis, R. L. (2017). Natural based eumelanin nanoparticles functionalization and preliminary evaluation as carrier for gentamicin. Reactive and Functional Polymers, $114,38-48$.

[28] Dezidério, S. N., Brunello, C. A., Da Silva, M. I. N., Cotta, M. A., and Graeff, C. F. O. (2004). Thin films of synthetic melanin. Journal of non-crystalline solids, 338, 634-638. 